\title{
Pengaruh Model Pembelajaran Course Review Horay terhadap Kemampuan Pemahaman Konsep Matematis Berdasarkan Kemandirian Belajar Siswa SMK Pekanbaru
}

\author{
Ramon Muhandaz ${ }^{1)}$, Ovi Trisnawita ${ }^{2}$, Risnawati ${ }^{3)}$ \\ ${ }^{1,2,3}$ Program studi pendidikan matematika, Universitas Islam Negeri Sultan Syarif Kasim Riau \\ e-mail: ramon.muhan@uin-suska.ac.id
}

\begin{abstract}
ABSTRAK. Penelitian ini bertujuan untuk mengetahui pengaruh penerapan model pembelajaran Course Review Horayterhadap kemampuan pemahaman konsep matematis berdasarkan kemandirian belajar siswa Sekolah Menengah Kejuruan Pekanbaru. Model pembelajaran Course Review Horaydipilih karena model tersebut membantu siswa untuk memahami konsep dengan baik melalui diskusi kelompok. Penelitian ini merupakan penelitian Quasi Eksperimendan desain yang digunakan adalah Faktorial Eksperimental. Populasi dalam penelitian ini adalah seluruh siswa kelas X Sekolah Menengah Kejuruan Taruna Pekanbaru. Sampel dalam penelitian ini adalah kelas X TKJ sebagai kelas eksperimen dan kelas X TSM sebagai kelas kontrol. Teknik pengambilan sampel yang digunakan dalam penelitian ini adalah Cluster Random Sampling. Instrumen yang digunakan adalah tes uraian untuk mengukur kemampuan pemahaman konsep matematis dan angket untuk mengukur kemandirian belajar siswa. Teknik analisis data dilakukan menggunakan uji $t$ tes untuk semua hipotesis. Berdasarkan uji tes $t$ yang dilakukan untuk hipotesis 1, 2 dan 3 diperoleh $t$ hitung $>t$ tabel, artinya $H_{1}$ diterima. Sehingga dapat disimpulkan bahwa terdapat perbedaan antara kelas eksperimen yang belajar dengan menggunakan model Course Review Horay dengan kelas kontrol yang belajar dengan menggunakan pembelajaran konvensional. Dengan rata-rata skor pada kelas eksperimen lebih baik dari rata-rata skor kelas kontrol. Sedangkan untuk hipotesis 4 diperoleh $t$ hitung $\leq t$ tabel, artinya $H_{1}$ ditolak. Sehingga dapat disimpulkan bahwa tidak terdapat perbedaan antara kelas eksperimen yang belajar dengan menggunakan model Course Review Horay dengan kelas kontrol yang belajar dengan menggunakan pembelajaran konvensional. Dengan rata-rata skor sama untuk kelas eksperimen dan kelas kontrol. Hasil penelitian ini dapat digunakan guru dalam meningkatkan kualitas pembelajaran dikelas.
\end{abstract}

Kata kunci: : Course Review Horay, Kemampuan Pemahaman Konsep Matematis,Kemandirian Belajar Siswa, Eksperimen.

\section{PENDAHULUAN}

Pemahaman konsep matematis menurut beberapa pakar merupakan salah satu kemampuan matematika yang penting dimiliki dan dikuasi setiap siswa, karena pemahaman konsep matematis merupakan salah satu aspek yang hendak dikuasi demi tercapainya tujuan pembelajaran matematika yang tercantum padaPermendikbud Nomor 21 Tahun 2016.Selain itu, pentingnya kemampuan pemahaman konsep juga dikemukakan oleh Santrock (Hendriana, 2017: 3) yang mengatakan bahwa kunci dari pembelajaranadalah pemahaman konsep. Kemudian Zulkardi (Herawati dkk,2010: 71) mengemukakan mata pelajaran matematika menekankan pada konsep. Begitu pula dengan Hendrianadkk (2017: 3-4) mengemukakan bahwauntuk mengembangkan dan menguasi kemampuan matematis seperti, pemecahan masalah, komunikasi, penalaran sampai kemampuan berfikir kritis dan berfikir kratif matematis serta kemampuan matematis lainnya 
dengan baik, diperlukan adanya dukungan kemampuan pemahaman konsep yang dikuasi dengan baik. Berdasarkan pendapat pakar tersebut, pemahaman konsep matematis merupakan kemampuan dasar matematika yang penting dimiliki guna menguasai kemampuan matematika lainnya.

Pentingnya pemahaman konsep matematis dan besarnya peranannya dalam pembelajaran matematika, seharusnya kemampuan pemahaman konsep matematis sudah tertanam sejak dini dalam diri setiap siswa. Namun, berdasarkan fakta yang ada, pemahaman konsep matematis belum tertanam dalam diri setiap siswa. Hal ini ditunjukkandengan adanya hasil survei Programme for International Student Assessment (Guria,2015: 5) hasil survei tersebut memperlihatkan Indonesia memperoleh 386 rata-rata skor matematika dari 490 rata-rata skor Internasionaldan menduduki peringkat ke 63 dari 71 negara. Selain itu, hasil penelitian dari beberapa jurnal pendidikan, banyak peneliti matematika dari berbagai daerah di Indonesia yang meneliti berkaitan dengan pemahaman konsep matematis siswa. Adanya hal tersebut menunjukkan bahawa secara nasional pemahaman konsep siswa bermasalah dan perlu ditingkatkan lagi. Kemampuan pemahaman konsep matematis yang masih rendah juga terjadi pada tempat peneliti melaksanakan penelitian yang dibuktikan dengan perolehan hasil uji coba tes kemampuan pemahaman konsep yang diberikan kepada 29 siswa yang menunjukkan bahwa 75,86\% siswa memperoleh nilai dibawah KKM yaitu 75.

Menurut Purwanto (2006: 102) rendahnya pemahaman konsep matematis sebagai hasil belajar dipengaruhi oleh banyak faktor, dan cara mengajar adalah salah satu faktornya. Oleh sebab itu, diperlukannya upaya untuk menerapkan model pembelajaran yang tepat guna. Model Course Review Horay (CRH) dijadikan sebagai salah satu model pembelajaran yang direkomendasikan, karena Huda (2015: 230) mengemukakan bahwa pemahaman konsep siswa yang baik dapat diraih dengan bantuan diskusi kelompok dalam penerapannya melalui model pembelajaran CRH . Selain itu, Kurniasih\& Berlin (2016: 80) menambahkan bahwa model pembelajaran CRH ini dapat menciptakan suasana kelas menjadi meriah den menyenangkan.Model CRH juga didukung dengan adanya teori psikologi kognitif yaitu teori Gestalt yang dikemukakan oleh John Dewey (Suhermandkk, 2001: 49).

Berdasarkan uraian yang telah dikemukakan, terdapat keterkaitan pemahaman konsep matematis dengan model pembelajaran CRH. Jika dilihat berdasarkan kemandirian belajar siswa, ternyata kemandirian belajar siswa juga saling berkaitan dengan pemahaman konsep matematis dan model pembelajaran CRH. Menurut Afgani (2011: 5.60) dalam pembelajaran, kegiatan aktif yang dilakukan siswa untuk mencapai tujuan pembelajaran dan merupakan kegiatan yang mendukung kognisi, perilaku serta sikap merupakan upaya yang berasal dari kemandirian belajar siswa. Begitu pulalah model pembelajaran $\mathrm{CRH}$ yang dalam pelaksanaannya dapat membuat siswa aktif dan terlibat langsung dalam pelaksanaan pembelajaran. Kemudian, Lusiana (Ernawati, 2009: 2) mengungkapkan bahwa rendahnya pemahaman konsep yang dimiliki oleh siswa diakibatkan oleh banyak hal dan salah satunya adalah kemandirian belajar yang rendah pula. Berdasarkan pendapat yang telah dikemukakan, kemandirian belajar mempengaruhi kemampuan pemahaman konsep matematis sebagai hasil belajar yang diperoleh siswa.

Menurut Wiharno (Hendriana, 2017: 4) pemahaman konsep merupakan suatu kekuatan yang harus diperhatikan dalam pembelajaran matematika demi tercapainya pengetahuan matematika yang bermakna. Sedangkan menurut Kusumawati (2008: 235) dalam belajar matematika diperlukannya landasan penting untuk menyelesaikan masalah baik dalam matematika itu sendiri dan dalam kehidupan sehari-hari yaitu pemahaman konsep matematis. Sejalan dengan 
pendapat Kesumawati, Bani (2011: 13) juga menyatakan bahwa salah satu tujuan penting dalam belajar matematika adalah memiliki kemampuan pemahaman konsep matematis yang baik, dimana pemahaman konsep menegaskan bahwa dalam belajar matematika materi yang didapat bukan hanya sekedar mampu menyebutkan rumus saja, namun memerlukan kemampuan lain yang lebih dari itu. Pemahamanyang baik akan membuat siswa lebih mengerti dengan konsep yang sedang dipelajari.Menurut Seomarmo dalam Hendriana \& Utari (2014: 20) pemahaman konsep dibagi menajadi dua jenis yaitu "pemahaman komputasional, suatu pemahaman yang dapat menerapkan konsep atau rumus pada perhitungan rutin/ sederhana atau mengerjakan sesuatu secara algoritmik saja.pemahaman fungsional, suatu pemahaman yang dapat mengaitkan suatu konsep dengan konsep lainnya secara benar dan menyadari proses yang dilakukan". Mengukur kemampuan pemahaman konsep matematis diperlukannya suatu indikator, dan indikator yang digunakan pada penelitian ini merupakan indikator pemahaman konsep matematis menurut Kalpatrick dkk (Afrilianto, 2012: 196) yaitu:“(1) Menyatakan ulang konsep yang sudah dipelajari;(2) Mengklasifikasikan objek-objek berdasarkan dipenuhi atau tidaknya persyaratan untuk membentuk konsep tersebut;(3) Menerapkan konsep secara algoritma;(4) Menyajikan konsep dalam berbagai macam bentuk representasi matematika dan;(5) Mengaitkan berbagai bentuk konsep (internal dan eksternal matematika)". Penilaian yang digunakan dapat dilihat pada Tabel Pedoman Penskoran

Tabel 1. Pedoman Penskoran

\begin{tabular}{clc}
\hline Tingkat Pemahaman & Kriteria & Skor \\
\hline Tidak Paham & Tidak menjawab sama sekali & 0 \\
Miskonsepsi & $\begin{array}{l}\text { Ada menjawab, tapi konsep dan perhitungannya } \\
\text { salah semua }\end{array}$ & 1 \\
& $\begin{array}{l}\text { Memberikan informasi yang dibutuhkan dalam } \\
\text { menerapkan konsep, namun jawaban salah } \\
\text { Miskonsepsi Sebagian }\end{array}$ & $\begin{array}{l}\text { karenamenunjukkan kesalahan konsep dalam } \\
\text { menjelaskan }\end{array}$ \\
Paham Sebagian & $\begin{array}{l}\text { Jawaban hampir benar karena adanya sedikit } \\
\text { kesalahan perhitungan dan membuat kesimpulan }\end{array}$ & 3 \\
& $\begin{array}{l}\text { Perhitungan benar, jawaban benar dan mengandung } \\
\text { Paham Seluruhnya }\end{array}$ & 4 \\
\hline
\end{tabular}

Model pembelajaran CRH menurut Kurniasih\& Berlin (2016: 81) merupakan model pembalajaran yang menguji pemahaman siswa dengan adanya soal yang diberikan oleh guru, kemudian siswa secara berkelompok akan menuliskan jawaban pada kotak bernomor sesuai keinginan dan untuk kelompok siswa yang menjawab dengan benar berdasarkan hasil diskusi harus segera berteriak "Horay!" serta melanjutkannya dengan menampilkan yel-yel kelompoknya. Pelaksanaan model pembelajaran CRHyang diterapkan sesuai dengan langkah pembelajaran menurut Uno\& Nurdin (2012: 89) yaitu: “(1) Guru menyampaikan kompetensi yang ingin dicapai;(2) Guru mendemonstrasikan atau menyajikan materi;(3) Memberikan kesempatan siswa tanya jawab; (4) Untuk menguji pemahaman, siswa disuruh membuat kotak 9/16/25 sesuai kebutuhan dan tiap kotak diisi angka sesuai dengan selera masing-masing siswa;(5) Guru membacakan soal secara acak dan siswa menulis jawaban di dalam kotak yang nomornya disebutkan guru dan langsung didiskusikan, kalau benar diisi tanda benar $(\sqrt{ })$ dan salah diisi tanda salah $(\times)$; (6) Siswa yang sudah mendapatkan tanda $(\sqrt{ })$ vertikal, horizontal atau diagonal harus berteriak Horay! atau yel-yel lainnya; (7) Nilai siswa dihitung dari jawaban benar jumlah Horay! yang diperoleh dan terakhir adalah (8) Penutup". 
Menurut Winne (Amir\& Risnawati, 2014: 168) kemandirian belajarmerupakan cara seseorang untuk mengatur dan mengatasi masalah pengalaman belajarnya untuk tercapainya tujuan yang sudah ditargetkan. Kemudian Desmita (Suhendri, 2010: 34) menambahkan "ciri-ciri kemandirian belajar ditandai dengan adanya kemampuan menentukan nasib sendiri, kreatif dan inisiatif, mengatur tingkah laku, bertanggung jawab, mampu menahan diri, mampu mengambil keputusan sendiri, serta mampu mengatasi masalah yang dihadapi tanpa ada pengaruh dari orang lain". Kemandirian belajar yang dimiliki siswa dapat diukur dengan indikator kemandirian belajar, menurut Hendriana dkk (2017: 233) indikator kemandirian belajar terdiri atas sembilan indikator diantaranya: "(1) Inisiatifdan motivasi belajar;(2) Mendiagnosa kebutuhan belajar;(3) Menetapkan tujuan atau target dalam belajar;(4) Memonitor, mengatur serta mengontrol belajar;(5) Memandang kesulitan sebagai tantangan;(6) Memanfaat kandan mencari sumber yang relevan;(7) Memilih dan menerapkan strategi belajar dan;(8) Mengevaluasi proses dan hasil belajar serta;(9) Self eficacy/ konsepdiri/ kemampuan diri".

Berdasarkan paparan yang telah diuraikan, tujuan dalam penelitian ini melihat (1) Terdapat atau tidaknya perbedaan kemampuan pemahaman konsep matematis siswa yang belajar menerapkan model pembelajaran CRH dengan model pembelajaran konvensional;(2) Terdapat atau tidaknya perbedaan kemampuan pemahaman konsep matematis siswa berkemandirian belajar tinggi, sedang, maupun rendah yang belajar menerapkan model pembelajaran CRH dengan model pembelajaran konvensional

\section{METODE PENELITIAN}

Jenis penelitian ini adalah penelitian kuasi eksperimental atau eksperimen semu (Multiyaningsih, 2013: 86). Desain penelitian yang digunakan adalah Faktorial Eksperimental (Lestari dkk, 2017: 149). Desain ini memperhatikan adanya variabel moderator yang mempengaruhi suatu perlakuan. Adapun desain dari faktorial eksperimental yaitu:

Tabel 2. Desain Faktorial Eksperimenatal

\begin{tabular}{ccccc}
\hline $\boldsymbol{A}$ & $\boldsymbol{O}_{\mathbf{1}}$ & $\boldsymbol{X}$ & $\boldsymbol{Y}_{\mathbf{1}}$ & $\boldsymbol{O}_{\mathbf{2}}$ \\
\hline$A$ & $O_{1}$ & $C$ & $Y_{1}$ & $O_{2}$ \\
$A$ & $O_{1}$ & $X$ & $Y_{2}$ & $O_{2}$ \\
$A$ & $O_{1}$ & $C$ & $Y_{2}$ & $O_{2}$ \\
$A$ & $O_{1}$ & $X$ & $Y_{3}$ & $O_{2}$ \\
$A$ & $O_{1}$ & $C$ & $Y_{3}$ & $O_{2}$ \\
\hline
\end{tabular}

dengan $A$ : Pengambilan sampel secara acak, $O_{1}$ : Hasil Pretest, $X$ : Perlakuan (treatment) yang diberikan, $C$ :Kontrol terhadap perlakuan, $Y_{1}$ : Kemandirian Belajar Tinggi, $Y_{2}:$ Kemandirian Belajar Sedang, $Y_{3}$ : Kemandirian Belajar Rendah dan $\mathrm{O}_{2}:$ Hasil Posttest.

Kemandirian belajar peserta didik diukur dengan menggunakan angket yang diberikan pada kelas eksperimen dan kelas kontrol yang bertujuan untuk melihat dan mengelompokkan kemandirian belajar peserta didik menjadi tiga, yaitu tinggi, sedang dan rendah. Rancangan penelitian model pembelajaran dan kemandirian belajar terhadap kemampuan pemahaman konsep matematis yaitu: 
Tabel 3. Rancangan Hubungan Model Pembelajaran dan Kemandirian Belajar Terhadap Kemampuan Pemahaman Konsep Matematis Siswa

\begin{tabular}{|c|c|c|}
\hline \multirow{2}{*}{$\begin{array}{l}\text { Kemandirian Belajar } \\
\text { (Y) }\end{array}$} & \multicolumn{2}{|c|}{ Model Pembelajaran(A) } \\
\hline & $\mathrm{CRH}\left(\mathrm{A}_{1}\right)$ & Konvensional ( $\left.\mathrm{A}_{2}\right)$ \\
\hline Tinggi $\left(\mathrm{Y}_{1}\right)$ & $\mathrm{A}_{1} \mathrm{Y}_{1}$ & $\mathrm{~A}_{2} \mathrm{Y}_{1}$ \\
\hline Sedang $\left(\mathrm{Y}_{2}\right)$ & $A_{1} Y_{2}$ & $\mathrm{~A}_{2} \mathrm{Y}_{2}$ \\
\hline Rendah $\left(\mathrm{Y}_{3}\right)$ & $A_{1} Y_{3}$ & $\mathrm{~A}_{2} \mathrm{Y}_{3}$ \\
\hline
\end{tabular}

Populasi penelitian ini merupakan seluruh siswa kelas X SMK Taruna Pekanbaru. Selanjutnya, dilakukan pengambilan sampel dengan ketentuan bahwa semua populasi memiliki kesamaan rata-rata dan tidak memiliki perbedaan kemampuan diawalnya, maka terpilih secara acak kelas X TKJ 3 sebagai kelas eksperimen dan kelas X TSM sebagai kelas kontrol.Penentuan pengambilan sampel menggunakan soal pretest kemampuan pemahaman konsep matematis.

Instrumen yang digunakan dalam pelaksanaan penelitian yaitu:

1) Tes (Pretest dan Posttest) kemampuan pemahaman konsep, tahapan yang dilakukan yaitu: membuat kisi-kisi soal, memvalidasi soal pada ahli, melakukan uji coba soal. Uji coba soal dilakukan di SMAN 9 Pekanbaru Kelas X IPA 1 \& X IPA 3 yang sudah mempelajari materi yang diberikan, kemudian dilakukan analisis validitas, reliabilitas, daya pembeda dan tingkat kesukaran soal.Analisis validitas soal menggunkan rumus product moment, reliabilitas menggunakan rumus alpha dan daya pembeda serta tingkat kesukaran menggunakan rumus untuk soal essay. Kesimpulan hasil analisis 10 soal tes kemampuan pemahaman konsep yaitu seluruhnya valid dengan reliabilitas cukup tetap, daya pembeda dengan kriteria Sangat Baik 3, baik 2, cukup 2 dan kurang baik 3, dan tingkat kesukaran dengan kriteria mudah empat, sedang 4 dan sukar 2. Soal yang digunakan dalam penelitian berjumlah 7 soal terkecuali soal dengan daya pembeda yang kurang baik.

2) Angket Kemandirian Belajar, tahapan yang dilakukan yaitu: membuat kisi-kisi angket, memvalidasi angket pada ahli, melakukan uji coba angket. Uji coba angket dilakukan di SMK Farmasi Pekanbaru Kelas X Farmasi, kriteria dalam menjawab angket kemandirian belajar peneliti menghilangkan kriteria "Netral" untuk mempertegas jawaban responden. Kemudian dilakukan analisis validitas dan reliabilitas, dengan kesimpulan hasil analisis 36 angket kemandirian belajar yaitu 30 angket valid dan 6 tidak valid disertai dengan relibilitas angket dengan kriteria baik. Angket kemandirian belajar yang digunakan dalam penelitian berjumlah 30 butir pernyataan. Setelah dianalisis, angket disebarkan pada kedua kelas yang akan diteliti guna untuk mengetahui kelompok siswa yang berkamandirian belajar tinggi, sedang dan rendah sesuai dengan kriteriapada Tabel 4.

Tabel 4. Kriteria Pengelompokkan Kemandirian Belajar Siswa

\begin{tabular}{cc}
\hline Kriteria & Kategori \\
\hline$S R L \geq \bar{x}+s$ & Kelompok Tinggi \\
$\bar{x}-s<S R L<\bar{x}+s$ & Kelompok Sedang \\
$S R L \leq \bar{x}-s$ & Kelompok Rendah \\
\hline
\end{tabular}

Berdasarkan hasil analisis dan kriteria pengelompokkan kemandirian belajar siswa, diperoleh bahwa siswa dengan kemandirian belajar tinggi dikelas eksperimen berjumlah 6 orang dan dikelas kontrol berjumlah 5 orang, untuk siswa yang berkamdirian belajar sedang berjumlah 16 orang untuk dikelas eksperimen dan kelas kontrol. Sedangkan siswa yang berkemandirian belajar rendah dikelas eksperimen berjumlah 4 orang dan sis dikelas kontrol berjumlah 6 orang.

3) Lembar Observasi, Lembar observasi yang peneliti gunakan adalah daftar cek. Observer memberi tanda cek $(\sqrt{ })$ untuk menentukan seberapa terlaksananya kegiatan 
pembelajaranberdasarkan hasil pengamatan. Lembar observasiyang digunakan adalah lembar observasi gurudan lembar observasi siswa.

Instrumen yang telah dipaparkan digunakan untuk mengumpulkan data. Setelah data terkumpul, data akan dianalisis guna untuk mengetahui tujuan penelitian. Analisis data dilakukan dengan menggunakan uji statistika. Sebelum dilakukan uji statistika, data hasil tes akhir pemahaman konsep terlebih dahulu dianalisis dengan uji prasyarat yaitu uji kenormalan dan homogenitas. Berdasarkan hasil uji prasyarat barulah dilakukan uji statisika dengan kriteria ketentuan: (1) Jika analisis data uji prasyarat normal dan homogen, uji statistika yang digunakan adalah uji tes $t$; (2) Jika analisis data uji prasyarat normal tetapi tidak homogen, uji statistika yang digunakan adalah uji tes $t$ ' dan; (3) Jika analisis data uji prasyarat tidak normal, uji statistika yang digunakan adalah uji statistika non-paremetrik yaitu uji Mann Whitney $U$.

\section{HASIL DAN PEMBAHASAN}

Berdasarkan analisis yang dilakukan, hasil tes akhir kemampuan pemahaman konsepdipaparkan pada tabel 5

Tabel 5. Hasil Analisis Data Kemampuan Pemahaman Konsep

\begin{tabular}{cccccc}
\hline \multirow{2}{*}{ Kelas } & $\begin{array}{c}\text { Kemandirian } \\
\text { Belajar }\end{array}$ & $\begin{array}{c}\text { Banyak } \\
\text { Sampel }\end{array}$ & $\bar{c}$ & \multicolumn{3}{c}{ Skor Tes Akhir Akhir Pemahaman } \\
& Konsep Matematis & $\boldsymbol{X}_{\text {max }}$ & $\boldsymbol{X}_{\text {min }}$ \\
\hline \multirow{4}{*}{ Eksperimen } & Tinggi & 6 & 25,833 & 28 & 19 \\
& Sedang & 16 & 23,312 & 27 & 18 \\
& Rendah & 4 & 19,500 & 22 & 18 \\
& Keseluruhan & 26 & 23,307 & 28 & 18 \\
& Tinggi & 5 & 21,800 & & \\
\multirow{3}{*}{ Kontrol } & Sedang & 16 & 19,375 & 25 & 14 \\
& Rendah & 6 & 19,500 & 25 & 14 \\
& Keseluruhan & 27 & 19,851 & 25 & 14 \\
\hline
\end{tabular}

Tabel 5 menunjukkan bahwa rata-rata keseluruhan skor pemahaman konsep kelas eksperimen lebih tinggi jika dibandingkan dengan rata-rata kesuluruhan kelas kontrol. Hal ini berarti kemampuan pemahaman konsep matematis siswa kelas eksperimen lebih baik dari pada kelas kontrol.PadaTabel 5,juga menujukkan pemahaman konsep matematis berdasarkan kemandirian belajar.Rata-rata skor pemahaman konsep siswa berkemandirian belajar tinggi dan sedang kelas eksperimen lebih tinggi dari rata-rata skor pemahaman konsep matematis siswa berkemadirian belajar tinggi dan sedang kelas kontrol.Namun, untuk rata-rata pemahaman konsep matematis siswa berkamandirian belajar rendah kelas eksperimen dan kelas kontrol memiliki rata-rata skor yang sama. Berdasarkan kemandirian belajar, hal ini berarti pemahaman konsep matematis siswa yang berkemandirian belajar tinggi dan sedang sajalah kelas eksperimen lebih baik dari kelas kontrol. Selain itu, rata-rata skor kemampuan pemahaman konsep matematis perindikator juga menunjukkan bahwa kelas eksperimen lebih baik daripada kelas kontrol yang ditunjukkan pada grafik yang disajikan pada Gambar 1. 


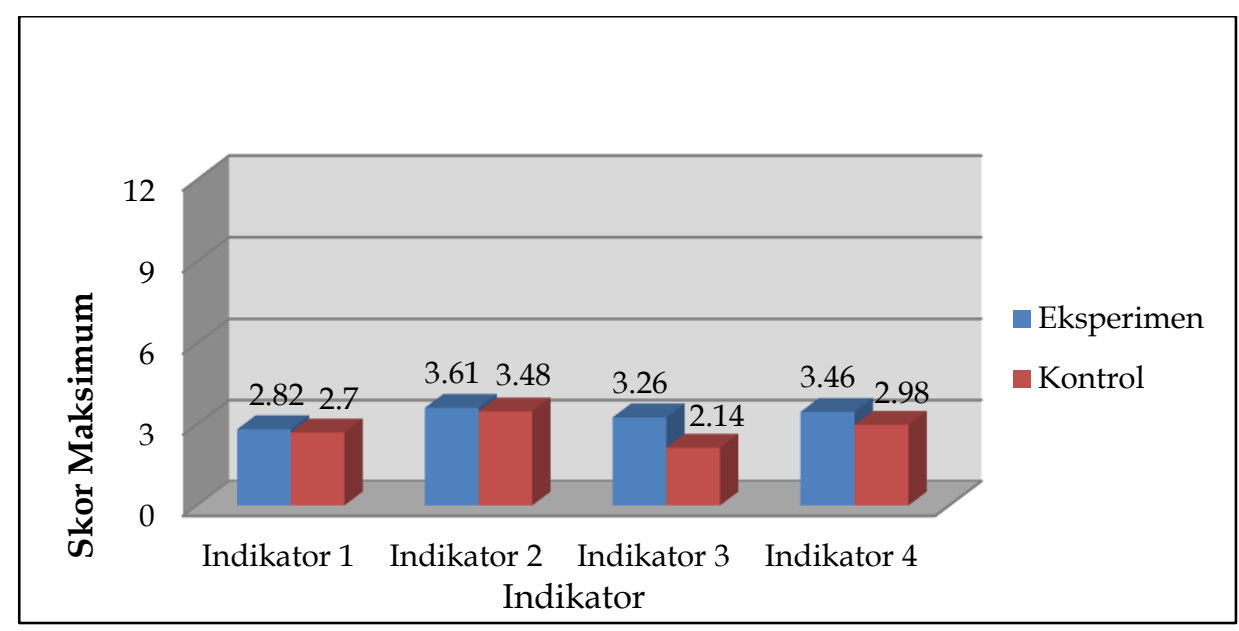

\section{Gambar 1. Rata-Rata Skor Indikator Kemampuan Pemahaman Kelas Sampel}

Hasil analisis pengujian hipotesis untuk kemampuan pemahaman konsep matematis siswa dapat diamati pada Tabel 6.

Tabel 6. Hasil Analisis Uji Hipotesis dengan Uji Tes $t$

\begin{tabular}{ccccc}
\hline Hipotesis & Model & Kemandirian Belajar & N & Hasil \\
\hline Hipotesis 1 & CRH & - & 26 & \\
Kipotesis 2 & Konvensional & - & 27 & \\
Hipotesis 3 & Konvensional & Tinggi & 6 & Terdapat \\
& CRH & Tinggi & 5 & Perbedaan \\
Konvensional & Sedang & 16 & \\
Hipotesis 4 & CRH & Sedang & 16 & \\
& Konvensional & Rendah & 4 & Tidak \\
& & Rendah & 6 & Terdapat \\
& & & & Perbedaan \\
\hline
\end{tabular}

Berdasarkan Tabel 6, dapat dilihat bahwa hipotesis 1,2 dan 3 menunjukkan terdapat perbedaan pemahamankonep siswa yang belajar menerapkan model pembelajaran CRH dengan siswa yang belajar dengan model konvensional dengan nilai $t$ hitung $>t$ tabel yaitu 3,733 $>$ 2,007. Sama halnya dengan siswa yang berkemandirian tinggi dan sedang yang menunjukkan terdapat perbedaan pemahamankonsep siswa yang belajar menerapkan model pembelajaran CRH dengan siswa yang belajar dengan model konvensional dengan nilai uji tes $t$ berturut-turut yaitu $t$ hitung $>t$ tabel yaitu 2,300 $>2,262$ dan $t$ hitung $>t$ tabel yaitu 3,152 $>2,042$.. Sehingga, analisis tersebut membuktikan bahwa secara keseluruhan dan untuk siswa berkemandirian tinggi dan sedang model pembelajaran $\mathrm{CRH}$ lebih baik untuk meningkatkan pemahaman konsep matematis dibandingkan dengan model pembelajaran konvensional.

Namun, berbeda untuk siswa yang berkemandirian belajar rendah yang menunjukkan tidak terdapat perbedaan kemampuan pemahaman masalah siswa yang belajar menerapkan model pembelajaran CRH dengan siswa yang belajar dengan model konvensional karenat hitung $<t$ tabel yaitu $0<2,306$.Memperkuat hasil analisis yangtelah dikemukakan, peneliti juga melampirkan perbandingan lembar jawaban siswa kelas eksperimen dan lembar jawaban siswa kelas kontrol berturut-turut pada Gambar 2 dan Gambar 3 


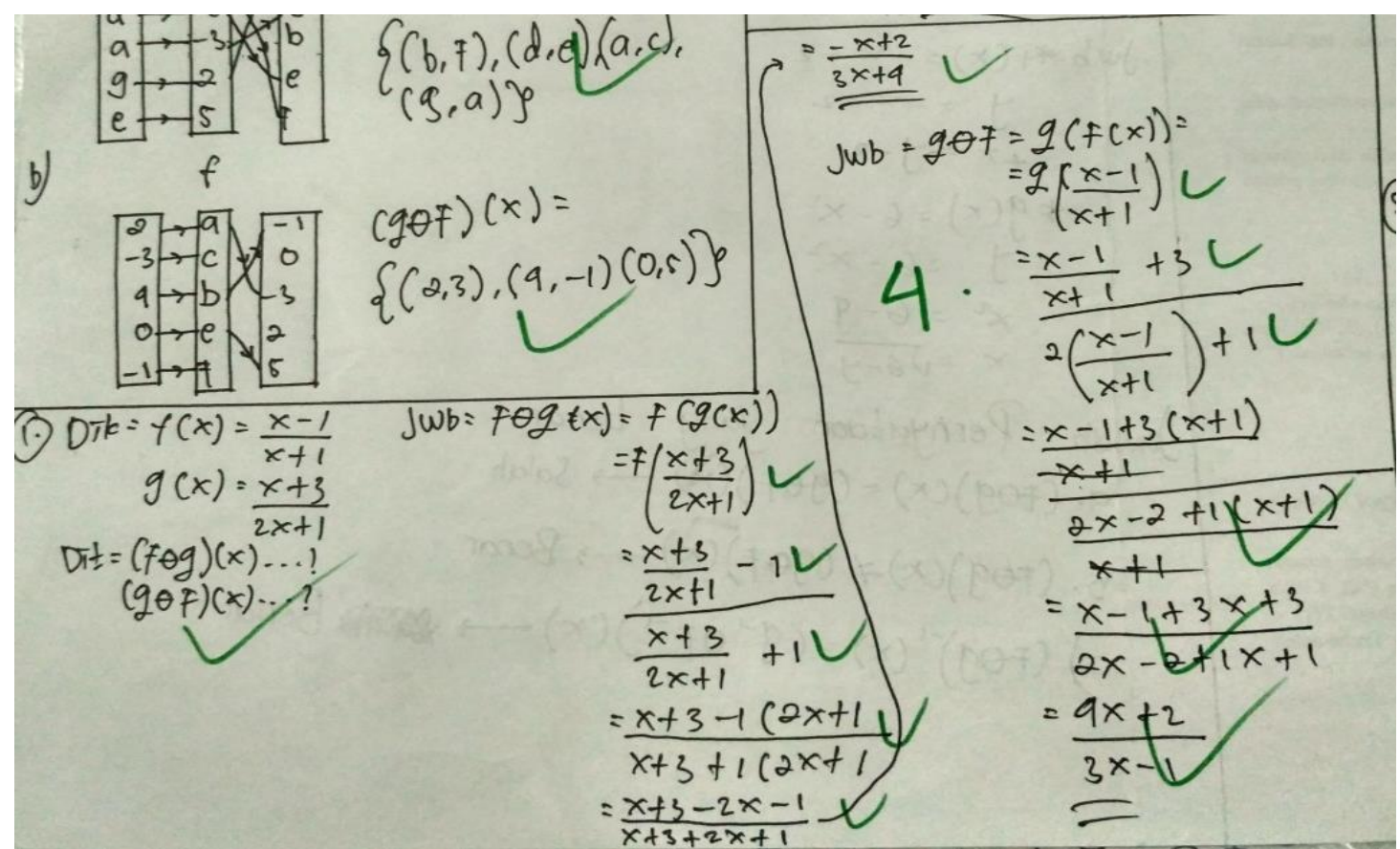

Gambar 2. Jawaban Siswa Kelas Eksperimen

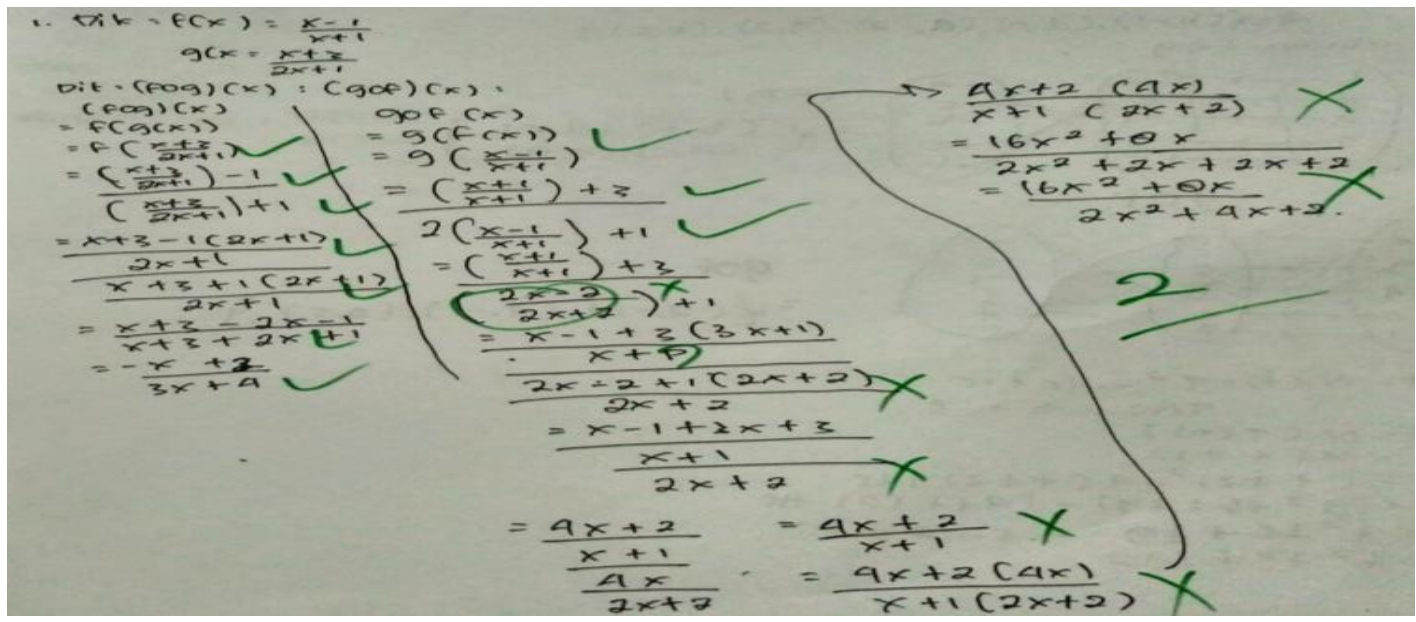

Gambar 3. Jawaban Siswa Kelas Kontrol

Pada Gambar 2 dan Gambar 3, kelas ekperimen mampu menjawab soal pemahamn konsep dengan benar, baik itu dalam menggunakan konsep dan melakukan perhitungan yang ditunjukkan dengan diperolehnya skor maksimal. Sedangkan kelas kontrol masih menunjukkan adanya kesalahan dalam memahami seuatu konsep dan kesalahan dalam melakukan perhitungan.

Sejalan dengan analisis tersebut, telah dijelaskan sebelumnya bahwa model pembelajaran CRH adalah model pembelajaran yang membantu siswa memahami konsep dengan baik. Begitu pula dengan kemandirian belajar yang ikut berperan dalam penerapan model CRH dan ikut mempengaruhi pemahaman konsep matematis siswa. 


\section{KESIMPULAN}

Berdasarkan hasil dan pembahasan, dapat disimpulkan bahwa: (1) Secara keseluruhan terdapat perbedaan kemampuan pemahaman konsep matematis siswa dan menunjukkan bahwa pembelajaran di kelas eksperimen dengan model CRH lebih baik dari pembelajaran di kelas kontrol dengan model konvensional; (2) Berdasarkan kemandirian belajar, terdapat perbedaan kemampuan pemahaman konsep matematis siswa berkemandirian belajar tinggi dan siswa yang berkemandirian belajar sedang, sehingga juga menunjukkan bahwa pembelajaran di kelas eksperimen dengan model CRH lebih baik dari pembelajaran di kelas kontrol dengan model konvensional. Namun, hal tersebut tidak berlaku untuk siswa berkemandirian belajarrendah karena tidak terdapat perbedaan antara siswa yang belajar menerapkan model CRH dengan siswa yang belajar dengan model konvensional.

\section{REFERENSI}

Afgani, J. 2011. Materi Pokok Analisis Kurikulum Matematika. Jakarta: Universitas Terbuka.

Afrilianto, M. 2012. Peningkatan Pemahaman Konsep dan Kompetensi Strategis Matematis Siswa SMP dengan Pendekatan Metaphorical Thinking. Infinity jurnal Ilmiah Program Studi Matematika STKIP Siliwangi Bandung. Vol. 01 No 2.

Amir, Z dan Risnawati 2014. PsikologiPendidikan. Pekanbaru:Suska Press.

Bani, A. 2011. Meningkatkan Kemampuan Pemahaman dan Penalaran Matematik Siswa Sekolah Mengah Pertama Melalui pembelajaran Penemuan Terbimbing, SPS UPI, Bandung. Edisi Khusus No.1. ISSN 1412-565X.

Ernawati, N. 2009.Efektivitas Pembelajaran Course Review Horay Terhadap Pemahaman Konsep Materi Pokok Bahasan Sudut Pada Siswa Kelas VII Semester II di SMP Al-Islami I Surakarta, Skripsi Universitas Mubammadiyah Surakarta, tidak diterbitkan.

Gurria, A. 2016. PISA 2015: PISA Result in Focus. PISA: OECD.

Hendriana, H dan Utari S. 2014.Penilaian Pembelajaran Matematika .Bandung: P'T. RafikaAditama.

Hendriana, H, dkk. 2017.Hard Skills dan Soft Skill Matematika Siswa. Bandung: PT.RefikaAditama.

Herawati, O.D.P, dkk. 2010. Pengaruh Pembelajaran Problem Posing Terhadap Kemampuan Pemahaman Konsep Matematika Siswa Kelas XI IPA SMA Negeri 6 Palembang. Jurnal Pendidikan Matematika, Vol.4 No.1. Tersedia di: http://eprints.unsri.ac.id/836/1/5_okti_70-80.pdf.

Huda, M. 2015. Model-Model Pengajarandan Pembelajaran: Isu-Isu Metodis dan Paradigmatis. Yogyakarta: Pustaka Belajar.

Istarani dan Muhammad R. 2014. 50 Tipe Pembelajaran Kooperatif, Medan: CV. Iscom Medan.

Kesumawati, N. 2008. Pemahaman Konsep Matematik dalam Pembelajaran Matematika. Semnas Matematika dan Pendidikan Matematika. 
Kurniasih, Idan Berlin S. 2016. RagamPengembangan Model Pembelajaran untuk Peningkatan Profesionalitas Guru.Jakarta: Kata Pena.

Lestari, K.E, dkk. 2017. Penelitian Pendidikan Matematika: Bandung: PT. Refika Aditama.

Mulyatiningsih, E. 2013. Metode Penelitian Terapan Bidang Pendidikan. Bandung: Alfabeta.

Purwanto, N. 2006. Psikologi Pendidikan. Jakarta: PT Remaja Rosdakarya.

Suhendri, H. 2010. Pengaruh Kecerdasan Matematika-Logis dan Kemandirian Belajar terhadap Hasil Belajar Matematika. Jurnal Formatif Vol.1 No. 1.

Suherman, H, dkk. 2001 Common Text Book: Startegi Pembelajaran Matematika Kontemporer. Bandung: JICA-UniversitasPendidikan Indonesia.

Uno, H.B dan Nurdin M. 2012. Belajar dengan pendekatan Pembelajaran Aktif Inovatif Lingkungan Kreatif Efektif Menarik: Strategi Pembelajaran P AILKEM merupakan salah satu strategi yang dapat Diterapkan Untuk. Mengoptimalkan Kegiatan Pembelajaran di Sekolah. Jakarta: PT. Bumi Aksara. 